\title{
The Impact of Accounting Information on Stock Prices: Evidence from the Athens Stock Exchange
}

\author{
Michalis Glezakos \\ University of Piraeus, Department of Insurance and Statistics \\ 80 Karaoli \& Dimitriou, 185 34, Piraeus, Greece \\ E-mail: migl@unipi.gr \\ John Mylonakis (Corresponding author) \\ 10, Nikiforou str., Glyfada, 166 75, Athens, Greece \\ E-mail: imylonakis@vodafone.net.gr \\ Charalampos Kafouros \\ M.A. University of Piraeus, Greece \\ E-mail: bkafouros@gmail.com \\ Accepted: December 13, 2011 \\ Published: February 1, 2012 \\ URL: http://dx.doi.org/10.5539/ijef.v4n2p56
}

Received: November 23, 2011

doi:10.5539/ijef.v4n2p56

\begin{abstract}
Past empirical research indicates that, in an increasing number of countries, certain accounting parameters affect the course of stock prices. Moreover, that this effect becomes stronger with time. The present study examines the impact of earnings and book value in the formulation of stock prices on a sample of 38 companies listed in the Athens Stock Market during the 1996-2008 period. The resulting evidence suggests that the joint explanatory power of the above parameters in the formation of $\sigma \tau$ ock prices increases over time. However, the impact of earnings is diminishing, compared to the book value, while investors strive towards analysing the fundamental parameters of businesses. Finally, multicollinearity was traced between the earnings and book value variables.
\end{abstract}

Keywords: Accounting information, Stock prices, Stock returns, Earnings per share, Book value, Multicollinearity JEL Classification Codes: G17, G11

\section{Introduction}

Historically, market data have always prevailed over accounting data when it comes to identifying the factors that affect stock prices. In the latest years, an increasing number of empirical studies indicate that the financial statements of enterprises contain certain parameters that play a critical role in the course of their respective equities in the stock market. This finding was not unexpected since after 2000 the international accounting standards were improved and established across the world. Therefore, the information offered to investors is now more accurate and enlightening than before.

The scope of this study is to examine the effect of the accounting information on the Athens Stock Exchange (ASE), by analysing data extracted from the financial statements of a sample of ASE listed companies.

\section{Past Literature}

The use of accounting data to explain changes in stock prices is frequently referred in the relevant literature. Collins, Maydew and Weiss (1997) have discovered that the joint explanatory power of earnings and book values has not declined in the last forty years. To the contrary, they asserted that their explanatory power has increased in the same period. This conclusion is reached by several other authors as Barth, Beaver and Landsman (1998) and Keener (2011, while Burgstahler and Dichev (1997) suggested that the function which describes the relationship between stock prices and earnings and book values is convex.

Also, Holthausen and Watts (2001) and Negakis (2005), after reviewing the relevant literature, concluded that earnings and book values do not affect in the same manner stock prices. Other studies (Hirschey et al., 2001; Aaker 
and Jacobson, 2001; Graham et al., 2002; Al-Harbi, 2003; Liang and Yao, 2005; Junttila et al., 2005; Tan and Lim 2007), have identified a variety of relationships between the above parameters. Finally, a number of researchers have provided evidence that the effect of earnings and book values on stock prices is different for different industries (Hughes, 2000; Boone, 2002; Riley et al., 2003; Zhao, 2010) or different countries (Filip and Raffournier, 2010; Alsaman, 2003; Martinez, 2003; Habib, 2004; Junttila et al. 2005; Goodwin and Ahmed, 2006; Ibrahim et al., 2009; Bo, 2009).

Chandra and Ro (2008) found that the value relevance of earnings and revenues remained constant over time, while Jenkings, Kane and Velury (2009) have proved that future business expectations kept value relevance of earning high. Canibao, Garcia-Ayuso and Rueda (1999) examined accounting data taken from Spanish companies, showing that the joint explanatory power of earnings and book values has not declined in the latest decades. However, their results demonstrated a slight decline in the marginal explanatory power of book values in relation to earnings.

The usefulness of accounting data in business evaluation was, also, evidenced by Ou and Penman (1989), Ohlson $(1989,1995)$ and Penman (1996). They explained a company's internal value by using accounting parameters and concluded that they can be used to identify stocks that have not been properly evaluated. They, also, expressed the view that the book value and earnings form the primary accounting variables which are used to interpret stock prices. Their findings are, also, supported by the empirical studies conducted by Lev (1996) and Francis and Schipper (1996), who examined data from the US market during the latest decades. They have, also, found that the explanatory power of accounting variables has declined.

On the other hand, Collins, Maydew and Weiss (1997) have expressed the opinion that the combined relevance of earnings and book values is progressively increasing over time. On the contrary, the relevance of extraordinary earnings appears to have decreased. They used an evaluation framework suggested by Ohlson (1995) which expresses a stock's value as a function of earnings per share and the book value per share. They applied regression analysis on stratification data and used $R^{2}$ as a measure of relevance. Their results are supported by the findings of Ely and Waymire (1996) and Francis and Schipper (1996), who concluded that the assumption of the relevance of accounting values could not be rejected. However, Lev (1996) and Ramesh and Thiagarajan (1995) reached entirely different conclusions suggesting that the relevance of earnings has declined over the years. Brown, Lo and Lys (1999) have provided similar evidence and have asserted that results to the contrary drawn by other studies are due to erroneous measurements of the $\mathrm{R}^{2}$.

Finally, Hayn (1995) suggested that small enterprises are more likely to report losses compared with larger enterprises. Therefore, their retention of earnings is less, which according to Ohlson's framework of assessment, leads to an increasing significance of book values in relation to earnings for the assessment of prices. In general, smaller companies are more likely to include other companies the value of which is led by the potential growth of their earnings (e.g. increase of excessive earnings observed in new companies) rather than their realisable earnings. This way, more emphasis is given on book values when valuation involves small businesses.

Hayn (1995) and Collins, Pincus \& Xie (1999) examined the explanatory power of losses. They found that these are not taken into account by investors as seriously as earnings. Their results are reinforced by the findings of Hayn (1995) who proved that the companies that present negative earnings have lower earnings response factors than those with positive earnings, assuming that this is due to the fact that stock holders always have the option of liquidation.

Similar findings are those of Basu (1997) who found out that bad news have a smaller impact on prices than good news and that if we fail to consider this diversified effect, we may face lower coefficients of determination $R^{2}$. The above suggests that the relevance of extraordinary profits should be reduced. In addition, extraordinary profits presented by companies are likely to be more temporary than main results. Basu, also, proved that the asymmetric response to bad and good news reduces the ability of earnings to interpret various performances. Kang (2003) has also found similar results.

On the other hand, Elliot and Douglas (1996) and Hayn (1995) found out that negative profits and extraordinary results can have a negative impact on the relevance of earnings. A decline in the relevance of earnings had been observed lately, as companies show negative profits and extraordinary results more often. The above are in line with the results reached by Barth et al. (1997), Berger et al. (1996), Burgstahler \& Dichev (1997), Collins et al. (1997) and Jan \& Ou (1995), who suggest that more emphasis needs to be paid on book values compared with earnings when the latter are negative or when part of them are characterised as extraordinary.

With regard to the ability of losses to explain price variations, Barth et al. (1996), Burgstahler and Dichev (1998), Collins, Pincus and Xie (1997), and Jan \& Ou (1995), after using the method of regression analysis on stratification 
data, report that relevance transfers from earnings to book values when earnings are negative or when companies face financial difficulties.

A different approach was followed by Garcia-Ayuso, Monterry and Pineda (1998), who examined the form of the functional relation between stock prices and companies' book values and earnings. They reached the conclusion that there is a convex relationship between stock prices and companies' earnings and book values. This relationship depends on the relative prices of earnings and book values rather than just on the ROE, as was suggested by Burgsthaler and Dichev (1998).

Barth, Beaver and Landsman (1996) showed that the explanatory power of earnings varies depending on a company's likelihood to declare bankrupt. An interesting essay is that of Canibano, Garcia-Ayuso and Sanchez (1999), who discovered that the amount of a company's intangible assets is associated with the price variation of its stocks.

Finally, Amir and Lev (1996) found out that in the case of high-technology businesses, accounting data can not explain stock price variations because the data of these companies change rapidly. Similar results were reached by Lev (1997) and Amir and Lev (1996), who showed that accounting data are of limited importance to investors when the companies under valuation operate in the services or high technology sector, investing in intangible assets (such as research and development, human resources and trademark development). Amir and Lev (1996), also, reported that earnings, book values and cash flows are highly irrelevant when the companies under valuation operate in the mobile telephones sector, which are intangible asset-intensive. If the above findings become generalised to other intangible asset-intensive industries, given that the presence of such companies increases every year, we should expect a temporal decline in the relevance of earnings, book values or both.

\section{Research Methodology}

For the purposes of this study, a sample of 38 companies listed in the ASE was randomly selected for the period 1996 to 2008. The data have been collected from the Datastream database. For each company, the logarithms of the yearly stock prices, earnings per share and book values per share have been used throughout the examined period. It is worth noting that the 38 sample companies were the same during the whole period under study.

The present analysis was based on the Ohlson's (1995) model which was developed according to the suggestions of Preinrich (1938), Edwards and Bell (1961) and Peasnell (1982). It expresses the stock price as a function of the earnings per share and the book value per share, as follows:

$$
P_{i t}=a+b E_{i t}+c B V_{i t}+e_{i t}
$$

where $P_{i t}$ is the stock price, $E_{i t}$ the earnings per share, $B V_{i t}$ the book value per share, and $e_{i t}$ is the part of the price which is not interpreted by the model (residuals).

Given that each regression was applied on the data for each year, the number of performed regressions was equal to the number of years of the sampling period. According to the applied methodology, the explanatory power of earnings and book values can be estimated by comparing the coefficients of determination of the following three models:

(a) The model which reflects the joint explanatory power of earnings and book value:

$$
P_{i t}=a_{0}+a_{1} E_{i t}+a_{2} B V_{i t}+\varepsilon_{i t}
$$

(b) It has been depicted that earnings and book values act, to a certain extent, as substitutes for one another and interact with each other. Therefore, it is expected that multicollinearity is present in equation (1.1). In order to overcome this problem, the explanatory power of earnings and book value is analyzed by using the equations (1.2) and (1.3) correspondingly.

$$
P_{i t}=\beta_{0}+\beta_{1} E_{i t}+\varepsilon_{i t}
$$

and

$$
P_{i t}=\gamma_{0}+\gamma_{1} B V_{i t}+\varepsilon_{i t}
$$

The models (1.1-1.3) produce the following coefficients:

$R_{T}^{2}=$ coefficient of determination of (1.1), expressing the volatility of $\mathrm{P}_{\mathrm{it}}$ which is explained by earnings per share and book value per share, jointly, 
$R_{E}^{2}=$ coefficient of determination of (1.2), expressing the volatility of $\mathrm{P}_{\mathrm{it}}$ which is explained by earnings per share, and

$R_{B V}^{2}=$ coefficient of determination of (1.3), expressing the volatility of $\mathrm{P}_{\mathrm{it}}$ which is explained by book value per share.

The incremented explanatory power of the book value $\left(\mathrm{R}^{2}{ }_{\mathrm{BVI}}\right)$ and earnings $\left(\mathrm{R}_{\mathrm{EI}}^{2}\right)$ are given by the following relationships:

$$
\begin{gathered}
R_{B V I}^{2}=R^{2}{ }_{T}-R_{E}^{2} \\
R_{E I}^{2}=R_{T}{ }^{2}-R_{B V}^{2}
\end{gathered}
$$

The explanatory power that is common for both earnings and book values $\left(R_{C}^{2}\right)$ is the result of the multiple model coefficient of determination less the above two parameters $\left(\mathrm{R}_{\mathrm{BVI}}^{2}, \mathrm{R}_{\mathrm{EI}}^{2}\right)$ :

$$
R_{C}^{2}=R_{T}^{2}-\left(R_{E I}^{2}+R_{B V I}^{2}\right)
$$

The above technique, which was proposed by Easton (1985) and Collins, Maydew and Weiss (1997) and applied by Theil (1971), examine whether the relevance of book values has changed over the years. More particularly, the coefficients of determination of equations (1.1), (1.2), (1.3), (1.4), (1.5) and (1.6) are related to a time variable (one at each time), as the following relationship shows:

$$
R_{t}^{2}=\lambda_{0}+\lambda_{\tau}(\text { Time })_{t}+\varepsilon_{t}
$$

where Time $=1 \ldots .13$ (the number of years of the sample).

The explanatory power of (1.7) declines in time if $\lambda_{1}$ is negative. On the other hand, the explanatory power increases in time if $\lambda_{1}$ is positive. The above are valid only if the coefficient is significant.

Combining relationships (1.4)-(1.6) the (1.8) is derived:

$$
\begin{aligned}
R_{c}^{2} & =R_{T}^{2}-\left(R_{T}^{2}-R_{B V}^{2}\right)-\left(R_{T}^{2}-R_{E}^{2}\right) \\
& =\left(R_{E}^{2}+R_{B V}^{2}\right)-R_{T}^{2}
\end{aligned}
$$

That is, when $R_{c}^{2}$ increases over time the earnings and book values act as substitutes for one another and interact with each other for the interpretation of prices. The phenomenon of multicollinearity therefore becomes more intensive.

\section{Research Results}

\subsection{The Sample Data}

The sample includes 38 randomly selected companies, which consist of the $10 \%$ of the companies listed in the Athens Stock Exchange (ASE). Their share Prices (P), annual Earnings per Share (EPS) and annual Book Value per Share (BVS) for the 13 year period (1996-2008) constitute the observations which were utilized for the purposes of this research. Finally, in order to enhance normality, the above figures were converted into their logarithmic counterparts.

As Table 1 reveals, it can reasonably be assumed that the distributions of the above stated parameters approximate the normal distribution. This conclusion is supported by the corresponding histograms presented in the Annex.

\subsection{Relationships between the Variables}

At this point, the coefficients of determination, which are of interest to this study, are calculated. More specifically, a linear regression is performed for each year, in order to measure the contemporaneous ability of earnings per share (EPS) and book values per share (BVS) to explain stock prices. After that, a regression is performed for each simple linear model by using only one explanatory variable each time. Then, the Joint-EPS differences are calculated based on relationship (1.4), the Joint-BVS based on relationship (1.5) and the Joint-(Incremental EPS + Incremental BVS) based on relationship (1.6). The results are shown in detail in Table 5.

The possibility of the existence of linear relationships between prices and earnings and book values was examined through the visual inspection of Diagrams 1 and 2 which were constructed by using the sample data of the current 
study. As the scatter plots show, price and EPS seem to have a linear relationship which is clearer than in the case of price and BVS.

In order to reach more accurate results, the corresponding linear regressions were run and their results are presented in Table 2. It is obvious that, the relevant figures support the linear relationship of the logarithmic prices with the logarithmic values of EPS and BVS. They, also, reveal that there exists a strong statistical significance of the calculated coefficients. The same conclusion is reached through the analysis of variance, which strongly reveals that $\mathrm{b} 1, \mathrm{~b} 2 \neq 0$ :

$$
F^{*}=\frac{M S R}{M S E}=176,33>F_{p-1, n-p(a)}=F_{2,370(0,05)}=3,02
$$

The Pearson correlation coefficients between $\ln$ (Price) and $\ln ($ EPS $)$ and $\ln$ (Price) and $\ln ($ BVS $)$ were also statistically significant, offering an additional support to the previously stated conclusions (Table 3). It is worth noting that the explanatory variables $\ln (\mathrm{EPS})$ and $\ln (\mathrm{BVS})$ were also significantly related. The above findings suggest that the application of equations (1.4)-(1.6) is necessary, in order to shed light in the cross relationships among the above three variables.

The coefficients of equations (1.1)-(1.3) are necessary to test the zero hypothesis of the non-existence of linear relationships between the main variables of this analysis; that is the EPS, BVS and Prices (P).

The general form of the performed test is the following:

$\mathrm{H}_{0}: \alpha_{1}=\alpha_{2}=\ldots=0 \Rightarrow$ No linear relationship exists between the dependent variable $\mathrm{Y}$ with the independent variable $\mathrm{X}$

$\mathrm{H}_{1}$ : One of the $\alpha_{\varepsilon}$ is not zero $=>$ The corresponding independent variable is linearly related to the dependent variable.

Table 4 summarises the coefficients of equations (1.1)-(1.3) on a yearly basis for the periods 1996-2008. According to the presented findings, the zero assumption is rejected for the multiple regression (1.1) against the alternative assumption that one of the $\alpha_{\mathrm{i}}$ values are not zero, given that all F-values are higher than their corresponding critical values. The critical value of $F$ is 3,35 .

Also, the coefficients of the logarithmic EPS and the logarithmic BVS were statistically significant in 22 out of 26 cases, thus suggesting a strong linear relationship between the regressed variables.

4.3 Estimating the Coefficients of DeterminationThe methodology used, as it is stated analytically in paragraph 3, is focused on the coefficients of determination. More specifically, linear regressions are performed on a yearly basis, by using as explanatory variables the EPS and the BVS according to equations (1.1)-(1.3). Then, equations (1.4)-(1.6) are calculated, by using the resulting coefficients of determination of the performed regressions. The results are summarised in Table 5. By applying these coefficients to equation (1.7) the following results are presented in Table 6 (p-values, indicating their level of significance, in parentheses).

Table 6 shows that the coefficients of the time variable $\left(\lambda_{1}\right)$ are positive in five out of six cases and that the explanatory power of book values follows an upward trend with an annual rate of $+4.9 \%$ during the 1996-2008 period. This rate is significantly higher than that of the explanatory power of earnings, which is negative (-3.3\%). Therefore, the results suggest that book values play an increasing role (over time), in the interpretation of stock prices while the reverse is true for earnings.

In order to examine the variation of explanatory power of EPS and BVS over time and reach better conclusions, it is worth describing the course of the Athens Stock Exchange General Index during the examined period. Diagram 3 shows the history of the General Index, in detail, over the period 1/1/1996 - 31/12/2009.

As Diagram 3 reveals, the General Index was increasing steadily since 1996 to September 1999. At the second half of that month, up to March 2003, prices followed a continuous fall. Finally, the situation was reversed during the period 3/2003 - 12/2007.

During the above period, the joint relevance of EPS and BVS was strong, as the coefficients of determination of the equations (1.4)-(1.6) suggest (Table 5) and Diagram 4 reveals. However, it should be noted that, on average, EPS exhibited a stronger explanatory power when the market was moving upwards, while the reverse was true for BVS.

The above findings are confirmed in Diagram 5 which presents the marginal explanatory power of BVS and EPS. More precisely, this Diagram shows the $\mathrm{R}_{T}^{2}, \mathrm{R}^{2}$ and $\mathrm{R}_{\mathrm{BV}}^{2}$ on a time context. It is observed that marginal explanatory power of book value reached its lowest levels at September 1999, before the sudden reverse of the market trend. This can be explained by the fact that, in the preceding years, the stock prices had so strongly risen, that price earnings ratios had dramatically increased, thus inducing the investors to avoid fundamental data. In fact, 
when the General Index (GI) reached its high level (September 1999), the book value could only explain 1.6\% of price variability, as opposed to $20-30 \%$ in average stock market periods.

\section{Conclusions}

In the latest years, academic research has shown that in an increasing number of countries, certain accounting parameters affect the course of stock prices and also that this effect becomes stronger with time.

In the context of the present study, the impact of earnings per share and book value per share, in the formulation of stock prices, was examined for a sample of companies listed in the Athens Stock Exchange during the period 1996-2008, by applying a methodology focusing on the coefficients of determination of the performed regressions.

The results suggest that the explanatory power of earnings and book value in the formulation of prices increases over time. It is also found that, in the last years, earnings appear to play an increasingly diminishing role in the interpretation of stock prices, compared with the book value. In an attempt to interpret this finding, it is assumed that investors strive more towards fundamental parameters of businesses, than stock market data.

The above results are coherent with the corresponding results of many relevant empirical studies, which were carried out in several stock markets of developed and developing countries.

\section{References}

Aaker, D. A., \& Jacobson, R. (2001). The value relevance of brand attitude in high-technology markets. Journal of Marketing Research, 38(4), 485-493.

Al Harbi, A.D. (2003). Do investors attach higher valuation weights to cash flow-based measures than to accrual-based measures in valuing intangible-intensive, high technology stocks? (Doctoral Dissertation, Florida Atlantic University).

Alsaman, A.M. (2003). The value relevance of accounting numbers and the implications for international accounting standards harmonization: Evidence from Saudi Arabia and Kuwait (Doctoral Dissertation, Florida Atlantic University).

Amir, E., \& Lev B. (1996). Value-Relevance of non-financial information: the wireless communications industry. Journal of Accounting and Economics, 22, 3-30.

Barth, M., Beaver, W., \& Landsman W. (1997). Valuation characteristics of equity book value and net income: tests of the abandonment option hypothesis. Working paper. Stanford University.

Barth, M.E., Beaver, W.H., \& Landsman, W.R. (1998). Relative valuation roles of equity book value and net income as a function of financial health. Journal of Accounting \& Economics, 25(1), 1-34.

Basu, S. (1997). The conservatism principle and the asymmetric timeliness of earnings. Journal of Accounting and Economics, 24(1), 3-37.

Berger, P., Ofek E., \& Swary I. (1996). Investors valuation of the abandonment option. Journal of Financial Economics, 42, 257-287.

Bernard, V.L. (1994). Accounting-based valuation methods, determinants of market-to-book ratios and implications for financial statement analysis. Working paper, University of Michigan.

Bo, J. (2009). An empirical study on information content of accounting earnings and cash flow. Journal of Modern Accounting and Auditing, 5(7), 44-48.

Boone, J.P. (2002). Revisiting the reportedly weak value relevance of oil and gas asset present values: The roles of measurement error, model misspecification and time period idiosyncrasy. Accounting Review, 77(1), 73.

Brown, S., Lo, K., \& Lys, Th. (1998). Use of R-squared in Accounting Research: Measuring Changes in Value Relevance over the Last Four Decades. November 24, Sauder School of Business Working Paper, Available at SSRN: http://ssrn.com/abstract $=141056$ or doi:10.2139/ssrn.141056

Burgstahler, D.C., \& Dichev, I.D. (1997). Earnings, adaptation and equity value. Accounting review, 72(2), 187

Burgsthaler, D., \& Dichev I. (1998). Earnings, adaptation, and equity value. The Accounting Review, 72, 187-215.

Cañibano, L., García-Ayuso, M., \& Sanchez P. (1999). "f”. Working paper. Autonomous University of Madrid.

Chandra, U., \& Ro, B.T. (2008). The role of revenue in firm valuation. Accounting Horizons, 22(2), 199-222.

Collins, D., Pincus, M., \& Xie, H. (1997). Equity valuation and negative earnings: the role of book value of equity.

Working paper, University of Iowa, Iowa City, IA. 
Collins, D.W., Maydew E.L., \& Weiss I. (1997). Changes in the value-relevance of earnings and book values over the past forty years. Journal of Accounting and Economics, 24, 39-67.

Collins, D.W., Pincus, M., \& Xie, H. (1999). Equity valuation and negative earnings: The role of book value of equity. Accounting Review, 79, 29-61.

Easton, P. (1985). Accounting Earnings and and Security Valuation: Empirical Evidence of the Fundamental Links. Journal of Accounting Research, Vol. 23, Studies on Accounting Earnings and Security Valuation: Current Research Issues, 54-77.

Edwards, O., \& Bell, O. (1961). The Theory and Measurement of Business Income. University of California Press, Berkeley.

Elliott, J., \& Douglas, H. (1996). Repeated Accounting Write-Offs and the Information Content of Earnings. Journal of Accounting Research, 34, 135-155.

Ely, K., \& Waymire, G., (1996). Accounting standard-setting organizations and earnings relevance. Working paper, Emory University, Atlanta, GA.

Filip, A., \& Raffournier, B. (2010). The value relevance of earnings in a transition economy: The case of Romania. The International Journal of Accounting, 45(1), 77-103.

Francis, J., \& Schipper, K. (1996). Have financial statements lost their relevance?. Working paper. University of Chicago.

García-Ayuso, M., Monterrey J., \& Pineda C. (1998). Empirical evidence on the convex relationship between prices, earnings and book values: the role of abnormal earnings in equity valuation. Working paper. University of Seville.

Goodwin, J., \& Ahmed, K. (2006). Longitudinal value relevance of earnings and intangible assets: Evidence from Australian firms. Journal of International Accounting, Auditing and Taxation, 15(1), 72-91.

Graham, C.M., Cannice, M.V., \& Sayre, T.L. (2002). The value-relevance of financial and non-financial information for internet companies. Thunderbird International Business Review, 44(1), 47-70.

Habib, A. (2004). Impact of earnings management on value-relevance of accounting information: Empirical evidence from Japan. Managerial Finance, 30(11), 1-14.

Hayn, C. (1995). The information content of losses. Journal of Accounting and Economics, 20, 125-153.

Hirschey, M. Richardson, V.J., \& Scholz, S. (2001). Value relevance of nonfinancial information: The case of patent data. Review of Quantitative Finance and Accounting, 17(3), 223.

Holthausen, R.W., \& Watts, R.L. (2001). The relevance of the value-relevance literature for financial accounting standards setting. Journal of Accounting \& Economics, 31(1-3), 3-75.

Hughes, K.E. (2000). The value relevance of nonfinancial measures of air pollution in the electric utility industry. Accounting Review, 75(2), 209.

Ibrahim, M.B.A., Bujang, H.F.B., Madi, N., Samah, A.B.A., Ismai, U.S.B., Jusoff, K., \& Narawi, A. (2009). Value-relevance of accounting number for valuation. Journal of Modern Accounting \& Auditing, 5(9), 30-39.

Jan, C., \& Ou., J. (1995). The role of negative earnings in the evaluation of equity stocks. Working paper, New York University, New York, NY and Santa Clara University, Santa Clara, CA.

Jenkings, D.S., Kane, G.D., \& Velury, U. (2009). Earnings conservatism and value relevance across the business cycle. Journal of Business \& Accounting, 36(9), 1041-1058.

Junttila, J., Kallunki, J., Karja, A., \& Martikainen, M. (2005). Stock market response to analysts' perceptions and earnings in a technology-intensive environment. International Review of Financial Analysis, 14(1), 77-92.

Kang, T. (2003). Trading volume as a proxy for other information in the returns-earnings regression. (Doctoral Dissertation, University of Illinois at Urban-Champaign).

Keener, M.H. (2011). The relative value relevance of earnings and book value across industries. Journal of Finance and Accounting, 6, 1-19.

Lev, B. (1996). The boundaries of financial reporting and how to extend them. Working paper, New York University.

Liang, C., \& Yao, M. (2005). The value-relevance of financial and nonfinancial information-evidence from Taiwan's information electronics industry. Review of Quantitative Finance and Accounting, 24(2), 135-157. 
Martinez, I. (2003). The impact of firm-specific attributes on the relevance in earnings and cash-flows: A nonlinear relationship between stock returns and accounting numbers. Review of Accounting and Finance, 2(1), 16-39.

Negakis, C.J. (2005). Accounting and capital markets research: A review. Managerial Finance, 31(2), 1-23.

Ohlson, J. A. (1989). Accounting earnings, book value, and dividends: The theory of clean surplus equation. Working paper, Columbia University, March.

Ohlson, J. A. (1995). Earnings, book values, and dividends in security valuation. Contemporary Accounting Research, 11, 661-688.

Ou, J., \& Penman, S. (1989). Financial Statement Analysis and the Prediction of Stocks Returns. Journal of Accounting and Economics, 11, 295-329.

Peasnell, E. (1982). Some Formal Connections Between Economic Values and Yields and Accounting Numbers. Journal of Business Finance \& Accounting, 2, 361-381.

Penman, S. H. (1996). The articulation of price-earnings ratios and Market-to-Book ratios and the evaluation of growth. Journal of Accounting Research, 34, 2, 235-260.

Preinrich, G. (1938). Annual survey of economic theory: the theory of depreciation. Econometrica, 6 /1, 219-241.

Ramesh, K., \& Thiagarajan, R. (1996). Inter-Temporal Decline in Earnings Response Coefficients. Working paper, Northwestern University.

Riley, R.A., Pearson, T.A., \& Trompeter, G. (2003). The value relevance of non-financial performance variables and accounting information: The case of the airline industry. Journal of Accounting \& Public Policy, 22(3), 231-254

Tan, P.M., \& Lim, C.Y. (2007). The value relevance of accounting variable and analysts' forecasts: The case of biotechnology firm. Review of Accounting \& Finance, 6(3), 233-253.

Theil, H. (1971). Introduction to Demand and Index Number Theory. University of Chicago, Centre for Mathematical Studies, USA

Weiss, C. H. (1997). How Can Theory-Based Evaluation Make Greater Headway?. Evaluation Review, 21 (4), 501-524

Table 1. Description of the analyzed variables

\begin{tabular}{|l|r|r|r|}
\hline & $\ln$ (Price) & $\ln ($ EPS) & $\ln$ (BVS) \\
\hline Mean & 1,286 & $-1,676$ & 1,081 \\
\hline Standard Deviation & 1,247 & 1,197 & 0,995 \\
\hline Skewness & $-0,208$ & $-0,102$ & 0,047 \\
\hline Kurtosis & 0,339 & $-0,153$ & 2,075 \\
\hline
\end{tabular}

Table 2. Summary statistics of the linear regressions between P, EPS and BVS

\begin{tabular}{|l|r|r|}
\hline Independent variable : Price $(\mathrm{P})$ & \multicolumn{1}{|c|}{ Coefficients } & \multicolumn{1}{|c|}{-test } \\
\hline Constant & $\mathrm{a}=2,063$ & 17,771 \\
\hline $\ln (\mathrm{EPS})$ & $\mathrm{b} 1=0,547$ & 14,153 \\
\hline $\ln (\mathrm{BVS})$ & $\mathrm{b} 2=0,298$ & 5,743 \\
\hline Adjusted $\mathrm{R}^{2}=48,5 \%$ & & \\
\hline
\end{tabular}


Table 3. Pearson correlations among the variables

\begin{tabular}{|c|c|c|c|}
\hline & $\ln$ (Price) & $\ln (\mathrm{EPS})$ & $\ln (\mathrm{BVS})$ \\
\hline $\begin{array}{l}\text { ln (Price) } \\
\text { Pearson Coefficient } \\
\text { Sig. (2-tailed) }\end{array}$ & 1 & $\begin{array}{r}0,666^{*} \\
0,000\end{array}$ & $\begin{array}{r}0,533^{*} \\
0,000\end{array}$ \\
\hline $\begin{array}{l}\underline{\ln (E P S)} \\
\text { Pearson Coefficient } \\
\text { Sig. (2-tailed) }\end{array}$ & $\begin{array}{r}0,666^{*} \\
0,000\end{array}$ & 1 & $\begin{array}{r}0,395^{*} \\
0,000\end{array}$ \\
\hline $\begin{array}{l}\underline{\ln (\mathrm{BVS})} \\
\text { Pearson Coefficient } \\
\text { Sig. (2-tailed) }\end{array}$ & $\begin{array}{r}0,533^{*} \\
0,000\end{array}$ & $\begin{array}{r}0,395^{*} \\
0,000\end{array}$ & 1 \\
\hline
\end{tabular}

* Significance at $1 \%$ level

Table 4. Regression coefficients

\begin{tabular}{|c|c|c|c|c|c|}
\hline \multicolumn{6}{|c|}{ Dependent variable : $\ln$ (Price) } \\
\hline & \multicolumn{3}{|c|}{$\begin{array}{l}\text { Multiple regression } \\
\text { Independent variables }: \ln (\mathrm{EPS}) \text { and } \ln (\mathrm{BVS}) \\
\alpha 1=\text { coefficient of } \ln (\mathrm{EPS}) \\
\qquad \alpha 2=\text { coefficient of } \ln (\mathrm{BVS})\end{array}$} & \multirow{2}{*}{$\begin{array}{r}\frac{\text { Simple regression }}{\beta 1=\text { coefficient of } \ln (\mathrm{EPS})} \\
\begin{array}{r}\beta_{1} \\
(\mathrm{t} \text {-test })\end{array}\end{array}$} & \multirow{2}{*}{$\begin{array}{l}\frac{\text { Simple regression }}{\mathrm{g} 1=\text { coefficient of }} \\
\ln (\mathrm{BVS}) \\
\\
\quad \begin{array}{r}\gamma_{1} \\
\text { (t-test) }\end{array} \\
\end{array}$} \\
\hline Year & $\begin{array}{r}\alpha_{1} \\
\text { (t-test) } \\
\end{array}$ & $\begin{array}{r}\alpha_{2} \\
\text { (t-test) }\end{array}$ & F-test & & \\
\hline 1996 & $\begin{array}{r}0.685 \\
(6.898)\end{array}$ & $\begin{array}{r}0.097 \\
(0.829)\end{array}$ & 35.722 & $\begin{array}{r}0.726 \\
(8.456)\end{array}$ & $\begin{array}{r}0.319 \\
(2.000)\end{array}$ \\
\hline 1997 & $\begin{array}{r}0.799 \\
(8.179) \\
\end{array}$ & $\begin{array}{r}0.315 \\
(2.879) \\
\end{array}$ & 43.579 & $\begin{array}{r}0.852 \\
(7.939) \\
\end{array}$ & $\begin{array}{r}0.666 \\
(3.721) \\
\end{array}$ \\
\hline 1998 & $\begin{array}{r}0.823 \\
(6.559) \\
\end{array}$ & $\begin{array}{r}0.341 \\
(2.708) \\
\end{array}$ & 32.593 & $\begin{array}{r}0.917 \\
(6.911) \\
\end{array}$ & $\begin{array}{r}0.563 \\
(3.163) \\
\end{array}$ \\
\hline 1999 & $\begin{array}{r}0.685 \\
(4.977) \\
\end{array}$ & $\begin{array}{r}-0.230 \\
(-1.412) \\
\end{array}$ & 12.438 & $\begin{array}{r}0.618 \\
(4.709) \\
\end{array}$ & $\begin{array}{r}0.117 \\
(0.757) \\
\end{array}$ \\
\hline 2000 & $\begin{array}{r}0.340 \\
(3.034) \\
\end{array}$ & $\begin{array}{r}0.209 \\
(1.388) \\
\end{array}$ & 8.538 & $\begin{array}{r}0.410 \\
(4.230) \\
\end{array}$ & $\begin{array}{r}0.416 \\
(2.762) \\
\end{array}$ \\
\hline 2001 & $\begin{array}{r}0.283 \\
(2.861) \\
\end{array}$ & $\begin{array}{r}0.634 \\
(4.593) \\
\end{array}$ & 21.798 & $\begin{array}{r}0.443 \\
(3.935) \\
\end{array}$ & $\begin{array}{r}0.801 \\
(5.924) \\
\end{array}$ \\
\hline 2002 & $\begin{array}{r}0.159 \\
(2.260) \\
\end{array}$ & $\begin{array}{r}0.755 \\
(7.378) \\
\end{array}$ & 49.189 & $\begin{array}{r}0.409 \\
(3.932) \\
\end{array}$ & $\begin{array}{r}0.640 \\
(5.124) \\
\end{array}$ \\
\hline 2003 & $\begin{array}{r}0.129 \\
(1.358) \\
\end{array}$ & $\begin{array}{r}0.633 \\
(4.905) \\
\end{array}$ & 37.629 & $\begin{array}{r}0.446 \\
(5.008) \\
\end{array}$ & $\begin{array}{r}0.758 \\
(9.739) \\
\end{array}$ \\
\hline 2004 & $\begin{array}{r}0.196 \\
(2.023) \\
\end{array}$ & $\begin{array}{r}0.820 \\
(6.068) \\
\end{array}$ & 55.943 & $\begin{array}{r}0.603 \\
(5.680) \\
\end{array}$ & $\begin{array}{r}1.021 \\
(9.767) \\
\end{array}$ \\
\hline 2005 & $\begin{array}{r}0.444 \\
(3.221) \\
\end{array}$ & $\begin{array}{r}0.648 \\
(3.781) \\
\end{array}$ & 34.738 & $\begin{array}{r}0.781 \\
(5.913) \\
\end{array}$ & $\begin{array}{r}0.831 \\
(6.152) \\
\end{array}$ \\
\hline 2006 & $\begin{array}{r}0.506 \\
(4.414) \\
\end{array}$ & $\begin{array}{r}0.427 \\
(2.711) \\
\end{array}$ & 31.949 & $\begin{array}{r}0.692 \\
(6.625) \\
\end{array}$ & $\begin{array}{r}0.972 \\
(6.743) \\
\end{array}$ \\
\hline 2007 & $\begin{array}{r}0.530 \\
(7.376) \\
\end{array}$ & $\begin{array}{r}0.275 \\
(2.648) \\
\end{array}$ & 65.117 & $\begin{array}{r}0.643 \\
(9.675) \\
\end{array}$ & $\begin{array}{r}0.746 \\
(7.995) \\
\end{array}$ \\
\hline 2008 & $\begin{array}{r}0.439 \\
(3.626)\end{array}$ & $\begin{array}{r}0.596 \\
(2.591)\end{array}$ & 26.316 & $\begin{array}{r}0.637 \\
(5.941)\end{array}$ & $\begin{array}{r}1.142 \\
(6.904)\end{array}$ \\
\hline
\end{tabular}


Table 5. Coefficients of determination of regressions (1.1) - (1.6)

\begin{tabular}{|r|r|r|r|r|r|r|}
\hline Year & $\mathrm{R}^{2}$ of eq. 1.1 & $\mathrm{R}^{2}$ of eq. 1.2 & $\mathrm{R}^{2}$ of eq. 1.3 & $\mathrm{R}^{2}$ of eq. 1.4 & $\mathrm{R}^{2}$ of eq. 1.5 & $\mathrm{R}^{2}$ of eq. 1.6 \\
\hline 1996 & 0.711 & 0.704 & 0.103 & 0.608 & 0.007 & 0.096 \\
\hline 1997 & 0.757 & 0.685 & 0.283 & 0.474 & 0.072 & 0.211 \\
\hline 1998 & 0.692 & 0.614 & 0.218 & 0.474 & 0.078 & 0.140 \\
\hline 1999 & 0.453 & 0.417 & 0.016 & 0.437 & 0.036 & -0.020 \\
\hline 2000 & 0.363 & 0.352 & 0.183 & 0.180 & 0.011 & 0.172 \\
\hline 2001 & 0.584 & 0.313 & 0.508 & 0.076 & 0.271 & 0.237 \\
\hline 2002 & 0.778 & 0.348 & 0.422 & 0.356 & 0.430 & -0.008 \\
\hline 2003 & 0.758 & 0.491 & 0.736 & 0.022 & 0.267 & 0.469 \\
\hline 2004 & 0.811 & 0.544 & 0.732 & 0.079 & 0.267 & 0.465 \\
\hline 2005 & 0.760 & 0.603 & 0.520 & 0.240 & 0.157 & 0.363 \\
\hline 2006 & 0.753 & 0.666 & 0.572 & 0.181 & 0.087 & 0.485 \\
\hline 2007 & 0.879 & 0.831 & 0.646 & 0.233 & 0.048 & 0.598 \\
\hline 2008 & 0.745 & 0.650 & 0.591 & 0.154 & 0.095 & 0.496 \\
\hline
\end{tabular}

Table 6. Coefficients of equation (1.7)

\begin{tabular}{|c|c|c|c|}
\hline & $\lambda_{0}$ & $\lambda_{1}$ & $\mathrm{R}^{2}$ \\
\hline $\mathrm{R}_{\mathrm{T}}^{2}$ & 0.578 & $0.017(0.124)$ & 0.202 \\
\hline $\mathrm{R}_{\mathrm{E}}^{2}$ & 0.489 & $0.010(0.447)$ & 0.054 \\
\hline $\mathrm{R}_{\mathrm{BV}}^{2}$ & 0.079 & $0.049(0.001)$ & 0.638 \\
\hline $\mathrm{R}_{\mathrm{EI}}^{2}$ & 0.499 & $-0.033(0.008)$ & 0.486 \\
\hline $\mathrm{R}_{\mathrm{BVI}}{ }^{2}$ & 0.090 & $0.007(0.475)$ & 0.047 \\
\hline $\mathrm{R}_{\mathrm{C}}$ & -0.011 & $0.042(0.001)$ & 0.635 \\
\hline
\end{tabular}




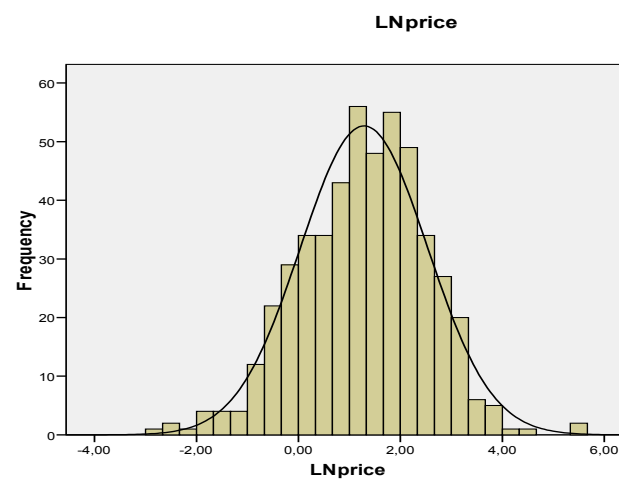

Mean $=1,29$
Stc. Dev 1,247
$N=494,247$

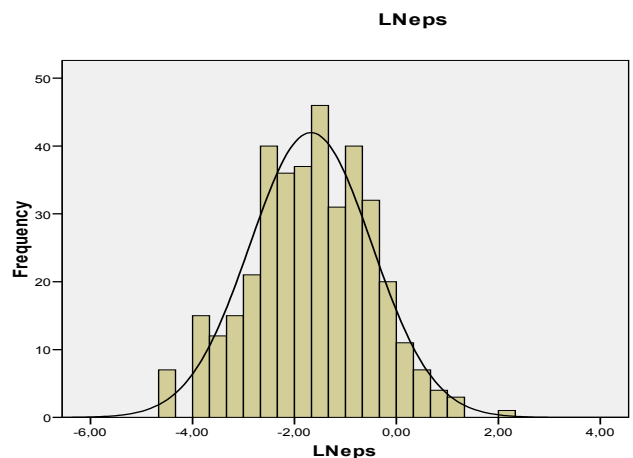

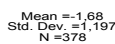

LNbv

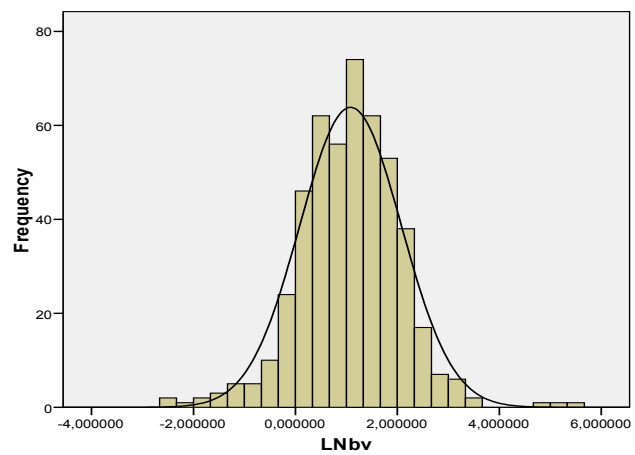

Mean $=1,081422$
Std. Dev. $=0.995695$

Histograms 


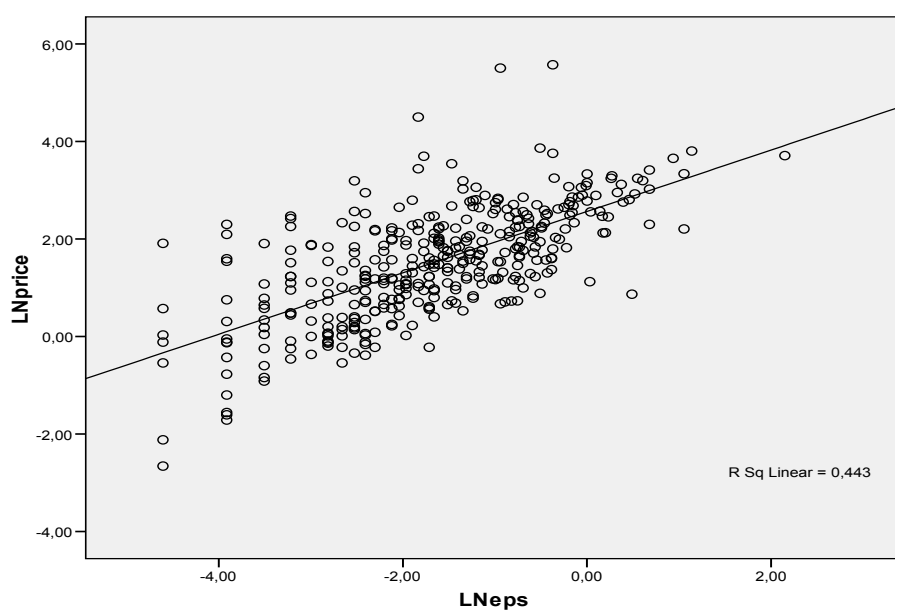

Diagram 1. Relationship between $\ln ($ EPS $)$ and $\ln$ (Price)

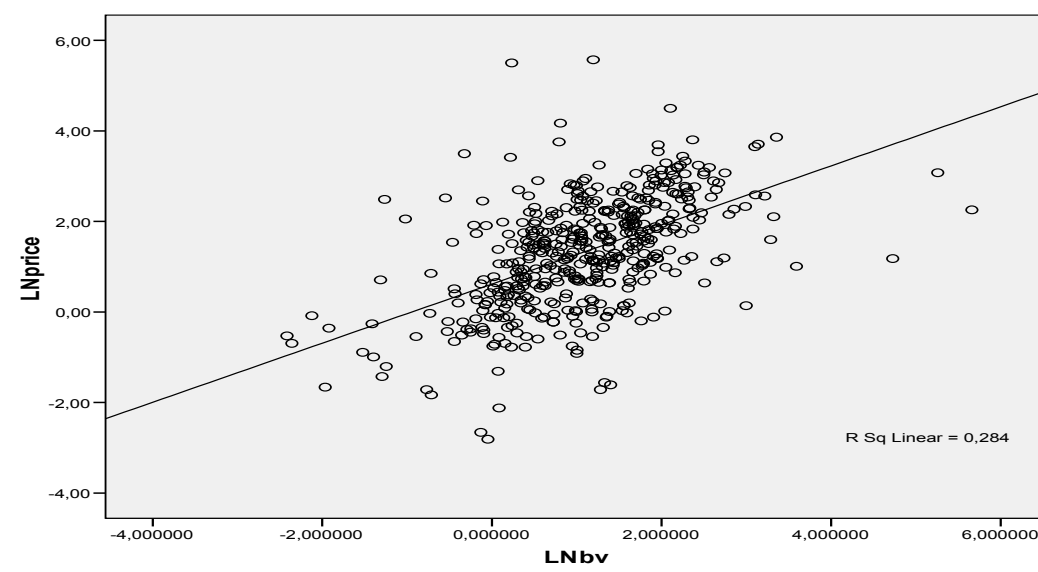

Diagram 2. Relationship between $\ln (\mathrm{BVS})$ and $\ln$ (Price)

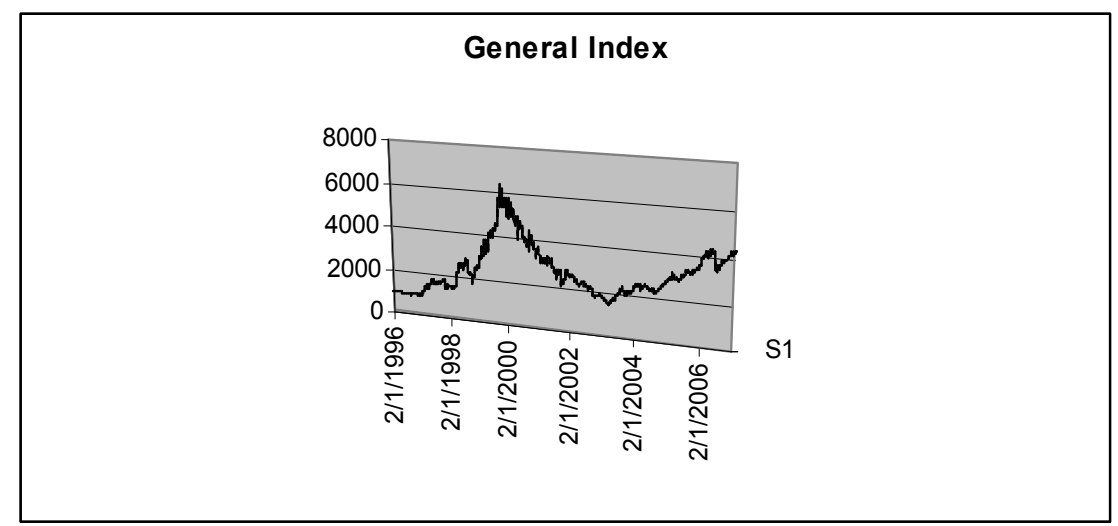

Diagram 3. Athens Stock Exchange - General Index 2/1/1996 to 31/12/2009 


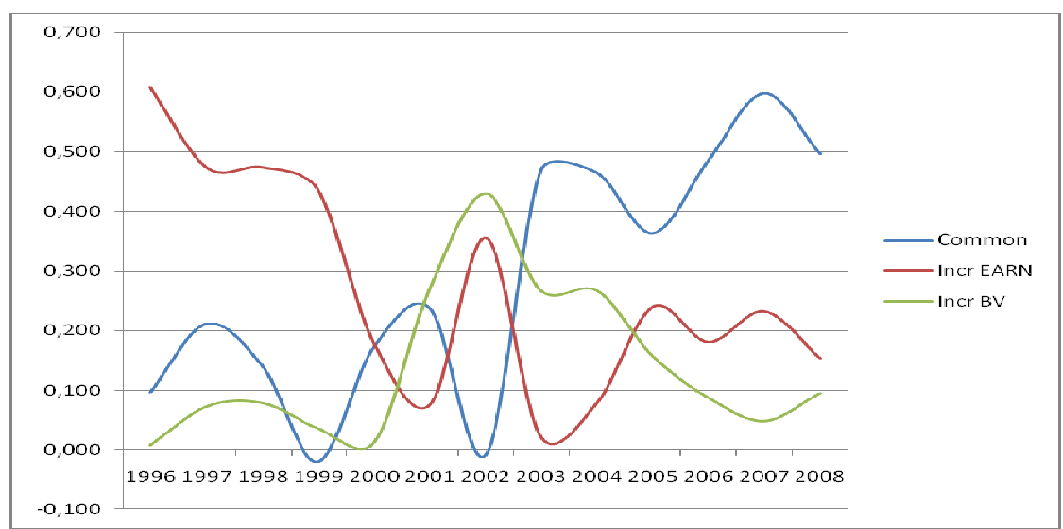

Diagram 4. Explanatory Power of Earnings and Book Values on ASE prices

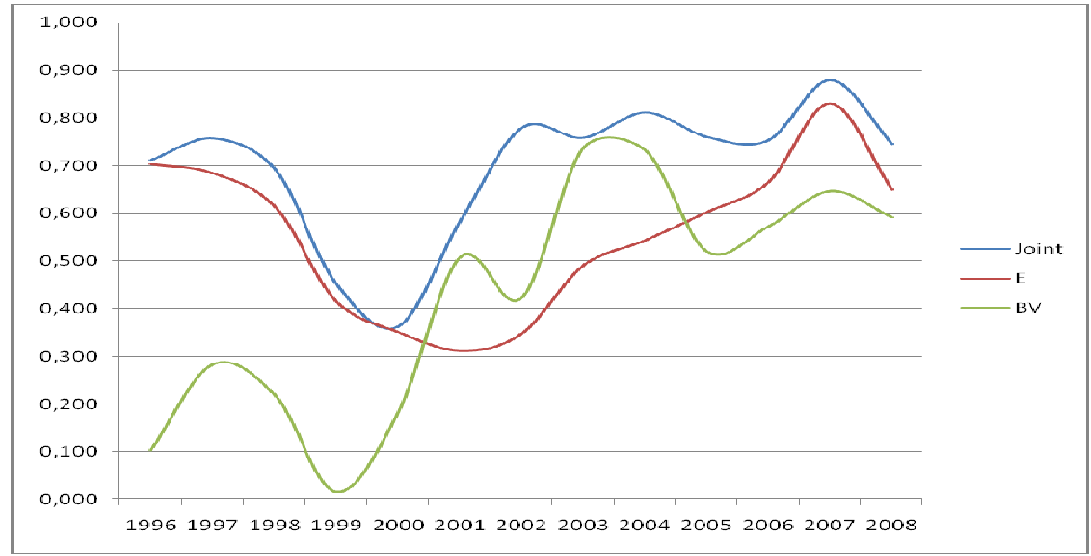

Diagram 5. Marginal Explanatory Power of Earnings and Book Values on ASE prices 